\title{
Citizenship and Religious Freedoms in Post-Revolutionary Egypt ${ }^{\dagger}$
}

Mohamed Fahmy Menza

check for

updates

Citation: Menza, Mohamed Fahmy. 2021. Citizenship and Religious Freedoms in Post-Revolutionary Egypt. Religions 12: 516. https:// doi.org/10.3390/rel12070516

Academic Editors: Waheeda Amien and Paul Morris

Received: 10 February 2021

Accepted: 2 June 2021

Published: 8 July 2021

Publisher's Note: MDPI stays neutral with regard to jurisdictional claims in published maps and institutional affiliations.

Copyright: (C) 2021 by the author. Licensee MDPI, Basel, Switzerland. This article is an open access article distributed under the terms and conditions of the Creative Commons Attribution (CC BY) license (https:/ / creativecommons.org/licenses/by/ $4.0 /)$.
Academy of Liberal Arts, American University in Cairo, AUC Avenue, New Cairo 11835, Egypt; mifahmy@aucegypt.edu

+ This paper is the outcome of a research project that was sponsored by the Arab Council of Social Sciences (ACSS) and the Swedish International Development Agency (SIDA). I'm immensely grateful to Alaa Moustafa Saad for the substantial support and valuable assistance she provided throughout the fieldwork phase upon which this writing is based.

Abstract: The majority of the social and political forces that spearheaded and actively participated in the 2011 and 2013 waves of uprisings catapulted the demands to reestablish 'citizenship' as one of the main foundations of a new social contract aiming at redefining state-society relations in a new Egypt. Meanwhile, the concept of citizenship has been increasingly featured in the discourse and practice of a wide variety of state actors and institutions. In fact, Egypt's experiences with the modern nation-state project concerning the conceptualization of citizenship, and the subsequent implications on religious freedoms and the role of religion in the polity at large, has gone through various ebbs and flows since the beginning of the 20th century. The concept of citizenship as such has faced a plethora of challenges and has been affected by the socioeconomic and political trajectories of statesociety relations during the Nasser, Sadat, Mubarak, and, most recently, Sissi regimes. Dilemmas of geographical disparities and uneven access to resources and services, in addition to issues of discrimination against ethnic and religious minorities such as Coptic Christians, Shiites, Nubians, Bedouins, or on the basis of gender, are among the main accompanying features of the neoliberal order that was introduced and then consolidated first by Sadat's Open Door and then Mubarak's state-withdrawal policies, respectively. To what extent did the conception and practice of citizenship rights and religious freedoms-as defined by state and non-state actors-change after the demise of the Mubarak regime? In addition, what is the role of the Egyptian civil society vis-a-vis the state in this process of conceptualizing and/or practicing citizenship rights and religious freedoms in the new Egypt? Focusing on the aforementioned questions, this paper aims at shedding some light on the changing role of religion in the Egyptian polity post 2011, while also highlighting the impact of the sociopolitical and economic ramifications witnessed within the society on the scope of religious liberties and citizenship rights as a whole.

Keywords: January 25 revolution; Islamist; Copts; Shiite; Baha'i; Muslim Brotherhood; state; Azhar; 2014 constitution; citizenship

\section{Introduction}

Social and political activists and intellectuals from the Arab region have often used the concept of 'citizenship' to denote a set of features pertaining to the foundational identity of the inhabitants of modern nation-states in Arab countries. Nonetheless, there seems to be a research gap when it comes to the scholarly contributions on the subject in the Arab context, especially with regard to fieldwork research that tackles the topic from an ethnographic standpoint. Among the available resources in the contemporary period, one notes that in the 1990s, a few studies were published on the question of citizenship in the Arab World (Butenschon et al. 2000; Joseph 2000), and later a book titled States Without Citizens (Jandora 2008) was also issued. Several contributors (Moghadam 2003; Abou-Habib 2011) also produced commendable studies on the status of citizenship in 
the Arab world. The bulk of these writings focused on specific (micro) features, such as issues of gender inequality and civil society activism. In the post-2011 phase, there were also significant contributions (Meijer and Butenschon 2017; Pizzo 2015) that attempted to analyze the ramifications of the Arab uprisings on the status of citizenship rights, with a focus on the major social and political forces active in Arab countries. However, there is still a need to revisit the concept of 'citizenship' from a holistic angle that incorporates primary resources and reflects the fieldwork realities experienced by the activists and practitioners on the ground. This endeavor is pivotal if we are to contextualize this subject in relation to the socioeconomic and the political underpinnings of the transformations witnessed in state-society relations in the Arab region.

\section{Conceptual Framework}

Generally speaking, the conceptualization of citizenship in the modern context has been closely tied to the development of the western model of the nation-state project. In this sense, citizenship emerged as a normative as well as an empirical (positive) notion. The normative dimension of the concept has usually been employed to describe the proactivity of the 'citizens' with regard to the public/political affairs of their communities, as opposed to the passivity of consumerism or to individualized societies and other typologies of social organizations, such as the networks that may work against the common good of the society. Elements of this approach could be traced in Jean-Jacques Rousseau's conception of the "Volonté Générale" and in Marxist and Hegelian ideas on the relationship between the individual and the modern state (Sater 2013). As such, citizenship is viewed as a process of attaining the 'common good' of the society, whereby the individual is mandated with the responsibility to proactively participate in the public sphere for the purpose of achieving that aim which should also yield the rights of all individuals (Jones and John 2002).

Another perspective on citizenship comes from the liberal/capitalist school, which views citizenship as based on a certain amalgam of rights. These rights include, but are not limited to, civil rights, such as the right to private property, the right to choose one's religion, and the right to privacy. These rights need to be protected by the state as it officiates its social contract with society. Henceforth, they could be considered as the basic foundations of the modern nation-state project, with its claims to the monopoly over the use of coercion and its responsibility to develop and exercise the rule of law. In the late 19th/early 20th Century, the notion of citizenship also widened to encompass the right to political participation, as well as the right to be protected from the potentially oppressive and coercive state apparatus. This included the rights to create political associations, vote, and strike. "The inclusion of socialist ideas in the late 19th century meant that the state would need to guarantee that these rights could be used in meaningful ways, thereby guaranteeing minimum welfare as part of the development of social rights ... [There are] three types of citizenship rights that have evolved since the 1800s: civil, political, and social rights" (Marshall [1959] 1973).

Within the Western context, a host of contributors have critiqued the notion of universal citizenship rights in modern political theory. Young (1989) notes that the conception of citizenship in modern political thought, and specifically in western liberal democracies, should be challenged on the basis that citizenship rights do not necessarily guarantee an equitable social contract between the modern nation-state and the various social and cultural subgroupings within the society. In a critique of the assumption that granting equal rights to 'citizens' is likely to erode various forms of biases and disadvantageous conditions under which such groups may duel, Young argues that acknowledging group difference is essential in order to minimize discrimination and oppression.

Applying the modern model of 'citizenship' with its variations on the Middle East with the assumption that there exist 'classical' citizenship rights as per the modern conception of the term would likely yield a wide variety of limitations. In the words of Nazih Ayubi, "In societies where theoretical individualism is weak and where classes are embryonic, neither the conventional liberal nor the conventional Marxist paradigms seem to be able to capture 
the realities of the situation" (Ayubi 1995). Thus, given the limitations pertaining to the aforementioned conceptions of citizenship, a 'back-to-basics' empirical approach may be more relevant when scrutinizing Middle Eastern polities (Sater 2013). Such an approach could help in shedding light on the dynamics of state-society relations in Arab states and the relevant trajectories of citizenship rights in the Arab polity, which arguably witnessed the formation of 'states without citizens', whereby the basic civil and political rights of even seemingly privileged groups were exposed to sizable infringements.

In this regard, the concept of the ethnocratic state in which the state's role is mainly to preserve the domination of one ethnic group, not that of the wider society, has also been employed by some analysts when scrutinizing state-society relations vis-à-vis citizenship rights in the Arab world (Butenschon et al. 2000). While this could be considered as an overgeneralization, given the sizable variations in state-formation experiences in various Arab countries, some features of that model have been evident in several cases, yet with different manifestations of groups-based domination over state structures. In several cases throughout the Middle East, religious majorities (Sunnis, Shiites, etc.), cliques of beneficiaries (businessmen, interest groups, etc.), and/or particular class typologies (military elite, state employees, etc.) exercised power leverages over state-society dynamics and imposed sorts of hegemony over state structures.

The study of citizenship in light of the wave of the Arab uprisings of 2011 could be quite beneficial when it comes to the production of knowledge pertaining to state-society dynamics in the Arab region and may also shed some light on the theoretical assumptions regarding the conceptualization of citizenship at large. One of the hypotheses that are often put forward is that citizenship rights are likely to gain momentum at times of sociopolitical mobilization. Again, the development of the Western polities in the 18th and 19th centuries seems to suggest that trajectory (Turner 2000). While it may still be early to reach conclusive findings in this regard when looking at the Arab uprisings, such an attempt may offer some insight concerning the prospects of sociopolitical transformation in the Arab region.

\subsection{On Egypt}

Egyptian intellectuals such as Qelada (1999) and Al Bishri (2004), among others, have argued that geographical as well as historical factors played a sizable role in creating a melting pot that formulated the basis of Egyptian identity over the two millennia that followed the birth of Christianity. As such, the interaction of both Islam and Christianity has resulted in a homogenous, albeit not always harmonious, relationship between the two religions, whereby a symbiotic process of co-existence and mutual acknowledgment was a vital component in the Egyptian polity since the Arab conquest. The Arabization of the Coptic Church and the protection of Copts under Muslim rule were among the most important facets of this relationship (Takawi 2012). In the post-1923 era, the principle of equality before the law and in the 'constitutional rights' given to both Muslims and Christians were also crucial features of this equation. ${ }^{1}$

Shami (2009) provides an important insight on the development of the concept of 'citizen' in Egypt in the early 20th Century, whereby the term 'minority' was rejected by several social and political forces, including the Coptic Church, for being inapplicable to the Copts, and instead, the notion of the 'citizen' and the attributes of Egyptian citizenship were the main foci of the public debate on nation-state building. An in-depth analysis of the historical progression of the notion of citizenship in Egypt can be attained by scrutinizing the censuses that took place in Egypt from 1882 until 1986. In doing so, one is able to observe the changes pertaining to the concept of being 'Egyptian' along the years and the different roles that race, religion and national origin played in defining Egyptian citizenship in various historical phases.

There has been also a dichotomy between the liberal and Islamist definitions of citizenship rights in the Egyptian context. Whereas some Islamic thinkers perceive that 'dhimmi' ${ }^{2}$ rights should be given to followers of Abrahamic religions as the only nonMuslim subjects acknowledged under the umbrella of the Islamic Umma, liberals, on 
the other hand, promote the concept of citizenship from the viewpoint of plurality and equality between the different religious, ethnic, and linguistic subgroups within the society, regardless of the dominant religion and under no particular umbrella apart from that of equal 'citizenship' rights for all subjects of the state.

Other schools of thought, such as pan-Arabism, also emphasized the centrality of the concept of citizenship and its essential role in fostering the nation-state model in Arab countries. In fact, most of the leading intellectuals that propagated the notion of panArabism in the Levant, Fertile Crescent, and Egypt in the early-mid 20th Century, such as Constantin Zureiq, Ba'athism proponent Michel Aflaq, and Jurji Zaydan were Arab Christians who believed in the paramount role of Arab culture as a driver for unity both within and among Arab states. However, the autocratic applications of the Arab nationalist project exemplified in the two renditions of Ba'athism in Syria and Iraq and the Nasserist model in Egypt and elsewhere didn't really reflect or catapult the essence of citizenship (Farah 2019). Despite the rhetoric that these regimes employed regarding citizenship rights, most of them witnessed different degrees of discrimination against religious and ethnic minorities and failed to deliver on their pledges of equal rights to all citizens, irrespective of their religious denominations or their ethnic, linguistic or cultural backgrounds.

\subsubsection{Disparities}

From a regional dimension, the executive authority of the modern state in Upper Egypt has been arguably weaker than it is in North Egypt. The main reasons for that are the sizable geographical distance and the relative strength of family and tribal connections in Upper Egypt, in particular vis-à-vis official institutions of state governance. Throughout the 1990s and 2000s, the government had to deal with a continuous state of turmoil in Upper Egypt that was characterized by a combination of an overall deteriorating socioeconomic status and a security threat posed by the increasingly powerful Islamic militants (Ghanem 2014). In the aftermath of the January 25 Revolution, these limitations pertaining to state presence were further exacerbated throughout the country at large and in Upper Egypt in specific.

Yet, on the public level, there is more reason to believe that, for the most part, the Egyptian state has been only paying lip service to the issue of citizenship rights. Some observers would cite the fact that this discourse of acknowledgment of Upper Egypt and the frontier governorates is nothing new, and that it has in fact been existent since the inception of the 1952 regime, albeit with no practical willingness or ability to alter this status quo on the part of the state. It could be argued that the Egyptian state has followed a "seasonal" strategy in dealing with these disfavored areas, issuing statements and decrees of special services and projects announced only during times of turmoil and tension, such as cases of terrorism, elections, or natural disasters (Soliman 2011). An example of that could be given with the most recent mention of North Sinai in the discourse of state officials post 2011, which only took place in the aftermath of the militant attacks in Sinai in the early-mid 2000s and the subsequent clashes that occurred between the police and military apparatuses, on the one hand, and the locals, on the other (Karkabi 2013).

On another note, the problem of these disfavored areas could be viewed as a structural one. It is rather insufficient for the state to pump in investments and expect a harvest, provided that the necessary means of production are lacking, including the proper infrastructure, the trained manpower, and so on. Hence, a strategy that is rather comprehensive is absent, which limits the capacity of the state to address the core of the issue in a way that surpasses the budgetary allocations which usually end up being ineffective in tackling the dilemma of geographical disparities.

When looking at the majority of development program interventions that have dealt with citizenship rights, one notes that several parallel transformations led to the increasing emphasis of development studies on citizenship rights projects since the late 1990s. On the one hand, the focus of participatory development programs, reflected in community projects, shifted gradually towards political participation and other areas of empowerment for disenfranchised classes/groups in order to increase influence over administrative 
decision-making institutions. On the other, there was also the rise of the 'good governance' agenda, which emphasized issues of decentralized and efficient systems of responsive governance. This also coupled with the emerging overlap between the fields of human rights and development represented in the ascendance of the 'rights-based approach' in the late 1990s. This approach was actually adopted by a number of organizations such as the UK Department for International Development (DFID) and UNDP.

In the case of Egypt, most of the civic education and awareness projects constituted the bulk of the developmental initiatives/activities taking place under the aforementioned agenda, which targeted comparatively limited societal segments and lacked a sound impact. In fact, most of the existing ways in which donors dialogue with the Egyptian state and the CSOs working on citizenship rights seem to be quite inefficient, as they lack a formalized sustainable structure than can nurture such interaction. Several analysts and practitioners have suggested that there is a research gap regarding the scope and magnitude of the impact of citizenship rights' initiatives in the Egyptian context. Some of the existing literature on such initiatives has criticized them for being largely politicized activities designed to maintain the political status quo whilst providing a facade of pluralism, attracting more donor funding along the way (El-Mahdi 2011).

\subsubsection{After The Spring}

In the aftermath of the Arab uprisings, a multitude of contributors also revisited the concept of 'citizenship' in the Arab world in an attempt to scrutinize the emerging changes relating to the notion. In 'Arab Cities after the Spring', the authors dissect the urban fabric of a plethora of Arab cities and observe the transformations in the citizens' perceptions of their own local communities in light of the uprisings. In that regard, a variety of writings note that significant shifts in power hierarchies as well as rationales and priorities of policymaking have been recurring features in a plethora of Arab polities post 2011, which means that the conceptualization of citizens' rights and responsibilities is in the process of redefinition in most of these locales (Stadnicki et al. 2014).

In these post-Spring contributions and others, there appears to be an underlying theme of redefining citizenship in terms of shared experiences, activities, and aspirations of certain social groups, rather than top-down features and characteristics determined or dictated by elite, mostly state, institutions. The common slogans, dress styles, and even tactics and strategies of political dissent observed among youthful segments throughout the region, and elsewhere, seem to suggest that a process of identity building is also in the making among this 'youth bulge' in Egypt and several other Arab countries. It could be argued that a social non-movement (Bayat 2007, 2013) also plays a paramount role in shaping how these youth groups formulate their perceptions regarding themselves and their social and cultural environments.

In Egypt, since the demise of the Mubarak regime, there have been several alterations in the dominant power relations within the polity. These changes have impacted the evolution of citizenship rights in Egypt and, subsequently, the rights discourses of political actors were not consistent at all times. The exercise of some rights has been enhanced at certain times during the transition, but they have been also exposed to attacks and constraints at other junctures. "In particular, those rights which require a new interpretation of religious and cultural traditions to support their expansion, such as religious freedom and gender equality, have often been obstructed" (Assad and Fegeiri 2014).

\section{Methodology and Fieldwork}

In order to tackle the research questions outlined earlier in this paper, the methodology aims at attaining a deeper analysis and a considerable degree of historical depth with regard to the conception of 'citizenship' and the practice of 'citizenship rights' in Egypt. In addition to the overview of historical developments relating to the evolution, or, at times, devolution of the notion of citizenship and the rights associated with it, which could be portrayed via desktop research and analysis of a variety of writings dealing with the topic, the research 
will also delve into questioning the application and awareness of 'citizenship rights' within the relevant social and political groups, including those that were involved in the January 25 and June 30 movements.

The research that the paper utilizes is based on qualitative fieldwork. It mainly employs a set of ethnographic tools to portray the experiences of the respondents via participant/observant mechanisms and snowball sampling techniques. What I aim to deliver here is a hands-on account of the experiences of some of the individuals and groups involved in fostering citizenship rights in Egypt pre and post 2011 and 2013. This exercise is needed, especially in light of the dearth of material on this subject matter from an ethnographic standpoint.

During the period from 2015 to 2017, the author held several meetings with interviewees from various backgrounds, including intellectuals, civil society practitioners, and activists and party politicians. The interviews targeted prominent as well as low-key grassroots activists and intellectuals involved in different capacities with the social and political movements which aimed at the promotion of citizenship rights over the past two decades. These informative meetings tackled a series of themes related to citizenship rights, including the issue of religious freedoms. Moving from the specific to the more general, the paper follows an inductive approach as it attempts to paint a holistic picture concerning the views and activities of this set of social and political forces towards issues of citizenship rights.

In these aforementioned meetings, some of the subtopics that materialized during and after the 2011 Revolution, such as citizenship from a legal perspective, the religious cases of Baha'is, and other religious minorities and Women's rights, to name a few, were further discussed and explored. Some of the figures interviewed in order to document and analyze these experiences include intellectuals and activists who have all been associated with a plethora of voluntary and professional initiatives closely linked to the theme of citizenship in the 2000s and 2010s. Their experiences were of paramount importance to the fieldwork. ${ }^{3}$

This sample of interviewees offered a multitude of angles from which 'citizenship' was viewed and dealt with. It is worth noting that the age-group and ideological background of the respondents played a major role in the way each of them perceived and defined citizenship. ${ }^{4}$ This variation can be attributed to the nature/context of the professional activities and the respective sociopolitical experiences that each of these actors have gone through. Throughout the research, the observation was that, more often than not, the relatively youthful activists who were directly and closely involved in the events of the January 25 revolution tended to focus more on civil and political aspects of citizenship vis-à-vis the more seasoned figures whose priorities rested within the realm of social and economic rights. Of course, this was not a general rule, and there were still multiple cases of youth actors, especially within the ranks of the leftist parties and groups, such as the Popular Alliance and the Bread and Freedom party, who were deeply engaged in episodes of socioeconomic activism. This diversity in of itself is one of the main aspects that this study will build upon as it attempts to decipher some of the features of citizenship in the Egyptian polity in the contemporary period.

\section{Geographical Context, Location, and Timeframe}

The research focuses on several geographical locales within two governorates-the first is Cairo and the second is Alexandria, the second biggest urban conglomerate in the country-with the aim of exploring how citizenship is defined and practiced in different communities in Egypt. Focus group discussions and open-ended interviews were conducted with the relevant stakeholders in three sectors: political party members, sociopolitical activists, and civil society practitioners.

Indeed, the question of citizenship rights is closely linked to unequal development between the center and the periphery on many levels. First off, the level of attention given by the state to the various areas/provinces and the capacity (or lack thereof) of the different social, regional, and cultural subgroupings within the society to influence state- 
level policymaking with their agendas is a reflective indicator of the degree of leverage such groups may have vis-à-vis the state. Second, the views and actions of the social and political forces operating on the central as well as the provincial levels provide a valuable insight into the nature and impact of the discourse and practice of 'citizenship' as perceived and dealt with in Cairo as opposed to Alexandria and other places in Egypt.

The writing also aims at analyzing the ideological discourse concerning citizenship within the political parties and social movements active in these areas via critically reviewing their platforms and stances towards citizenship rights. To do so, it is rather crucial to analyse the concept of 'citizenship' in relation to the popular uprising and new governmental actors, political forces, and processes at the local and national level. Factually, the active participation of a very diverse group of citizens from various socioeconomic backgrounds and classes was a reality happening during the 18-day Tahrir sit-in that led up to the demise of the Mubarak regime. It is still questionable whether the uprising has yielded any significant changes regarding the power relations shaping the discourse and practice of citizenship rights and if the civil society was able to play a role in such a process in the first place. In addition to the turbulent transitional phase that the country has gone through, which affected CSOs in general, two main factors also contributed to the hardships faced by CSOs working in the post-Mubarak phase in general: first, the wave of attacks orchestrated by the state against CSOs under the pretext of their being agents of foreign infiltration, and second, the rise of the Islamist forces from 2011 until the military takeover in 2013.

In the aftermath of the January 25 uprising, it has become more difficult for most NGOs working in the field of human rights to get the government to approve funding than to get to the funding itself following the infamous security crackdown that took place in late 2011. As a result, a multitude of NGOs have incurred frozen funds or funds awaiting the government's approval for quite a long time. In the long run, some NGOs-especially the smaller ones (community development associations, etc) — have witnesses a variety of existential risks, including closure and termination of activities.

\section{Background: The 2011-2013 Transition}

"The Arab Republic of Egypt is a sovereign state, united and indivisible, where nothing is dispensable, and its system is democratic republic based on citizenship and the rule of law ... Citizenship is a right to anyone born to an Egyptian father or an Egyptian mother. Being legally recognized and obtaining official papers proving his personal data is a right guaranteed and organized by law". ${ }^{5}$

Egypt's transition from a quasi-liberal single-party-led autocracy under Mubarak to a military-backed authoritarian system post 2013 has been a considerably tumultuous process. The main socioeconomic and political features of the post-revolutionary state were set in the aftermath of the 30 June 2013 movement, which put an end to two and a half years of attempted political transition into a democratic system and reconsolidated the political power of the newly reformed state with the backing of the military institution. Having said that, the actions and demands of some of the social and political forces that participated in the January 2011 Uprising concerning the spectrum of 'citizenship rights' were still present in the post-2013 phase. These entities and forces shared different conceptions relating to the notion of 'citizenship' as a set of rights that should be acquired by members of the society on the basis of them belonging to the Egyptian nation. Despite the fact that the call for consolidating such rights gained a sizable momentum among the sociopolitical forces that participated in the 18-day sit-in that ultimately led to Mubarak's removal in 2011, the period that ensued afterwards until July 2013 wasn't specifically as shiny as far as citizenship rights and religious freedoms are concerned.

The post-January-2011 period witnessed a general rise in the prowess of the Islamist forces on the social and cultural echelons, where factions such as the Muslim Brotherhood (MB) and the Salafists were, arguably, the most powerful and influential non-state political groupings on the official level. Ultimately, the Islamists amassed around two-thirds of the 
parliamentary seats in 2011, and then the MB's candidate, Mohamed Morsi, was elected as president in 2012. The 2011-2013 period was thus an opportunity for Islamists to readjust the foundational aspects of the state relating to the 'identity' and 'cultural domination' of Islamic ideology as per their view (Menza 2012a, 2012b). The Salafists, for example, attempted to enforce constitutional amendments to limit some of the rights stipulated in the 1971 constitution and succeeded to a considerable extent in doing so in the scrapped 2012 constitution, which ended up being dropped and replaced with the 2014 constitution that was drafted and voted upon in the movement after 30 June 2013 (Brown 2013).

This meant that the predominant discourse and practice of the driving forces within several state institutions dominated by these Islamist forces weren't particularly favorable towards issues of religious freedoms and minority rights. Coptic Christians largely felt threatened due to a bundle of perceived and clear and present risks to their wellbeing and livelihood, and religious minorities, such as Shiites and Baha'is were also frequently targeted by state policies as well as popular and social practices by groups that were either affiliated with or influenced by the MB and the Salafist factions. Examples include many incidents of internal displacement of Coptic communities, blocked access to places of worship of Christians in several locales, as well as cases of attacks and physical assaults on Shiite figures and communities, among other instances.

Meanwhile, the military-backed regime that emerged post 2013 employed the discourse of pro-religious freedoms and citizenship rights for minorities due to a variety of factors, among which is the fact that it based its legitimacy, in no small part, on its opposition to the Islamists that reigned supreme post January 2011. The widespread popular opposition to the MB's rule which was manifested in the massive 30 June 2013 demonstrations was culminated with the military takeover of political power in July 2013 and the following declaration of a transitional roadmap that effectively consolidated political power into the hands of the newly elected Minister-of-Defense-turned-President, Abdelfattah Al-Sissi. Throughout this period of consolidation, the security apparatuses within the state were determined to crush any form of Islamist opposition. Such a tendency was actualized in several episodes of brutal confrontations with the Islamists and epitomized by the violent dispersals of the Rabaa and Nahda sit-ins that led to the death of more than 1000 Islamist supporters at the time.

The newly reshaped state post 2013 was mainly backed by the military and the security apparatuses on the basis of the need to mitigate the threat emanating from the Islamist forces which were portrayed as extreme, violent, and importantly, antagonistic to religious minorities such as Coptic Christians. Of course, albeit somewhat exaggerated and quite generalized, these labels weren't all fallacies, and a lot of the Islamists did very little to foster a different image before and after 2013. Such claims were also reemphasized with the wave of attacks that was led by MB and Salafist supporters on Christian places of worship throughout the country, especially in Upper Egypt, as a retaliation for the Coptic Church's support for the July 3 military takeover.

The impact of this minority-protection approach might be questionable, as it clearly represents a case of top-down rather than bottom-up strategy. Although there is a lack of empirical data to substantiate that most of the Copts are satisfied by the support they received from the state in the aftermath of 30 June 2013, observational evidence and qualitative studies have shown that the post-2013 regime does enjoy a relatively high rate of approval among the majority of Coptic Christians due to a number of factors. First, the regime seems to be embarking on a process of drifting away from the policies and figures associated with the Islamists in different walks of life, so this, along with the perception shared by many Copts that it actually spared a lot of Christians the burdensome threat of an Egypt dominated by Islamists, means that President Sissi is quite popular among vast sections of the Christian community. Second, the post-2013 state has also been active in working on reforming some of the existing laws and structures that were previously utilized to discriminate against Copts for a long period, such as the law concerning the right to build places of worship, which was modified only recently by the state in order to 
allow for Coptic Christians to build—at least-one new church in every new town or city to be founded. In addition, the regime led the process of changing the electoral law, allowing for a specific quota of three Coptic Christian names on every list of candidates running for the Parliament. As a result, the 2020 parliamentary elections witnessed the introduction of 31 Christian MPs to the Parliament, a figure that could increase if the President decides on nominating more Copts for the presidential parliamentary appointees. Presidential appointments of several cabinet ministers from the Christian faith have also increased considerably compared to the Mubarak regime.

Such state-led policies are indeed worthy of mention and cannot be overlooked when assessing the changes pertaining to citizenship rights of the Coptic Christians post 2011. In spite of these interventions, the fact remains that in the peripheral and rural areas, cases of discrimination and abuse against Christians still take place, with the state's judiciary and executive branches incapable (or at times unwilling) to enforce legal measures to limit such violations. In addition, the predominant decline in the overall status of human rights throughout the country and the growing limitations on all forms of freedom of expression, assembly, and association showcase the unsustainability of this equation of state-led citizenship advocacy. Some of the policies and practices implemented by state institutions towards religious and other minorities appear to be, in many ways, conflicting and ambiguous with regard to their freedoms and liberties. This trend is a continuation of the approach of the post-1952 state, which has attempted to 'nationalize' the discourse pertaining to Islamic piety and values and also monopolize it, so that it is only allowed to emanate from state or state-friendly entities. In that regard, such entities have often employed Islamic rhetoric, at times, to showcase the state's piety and compete with the other non-state Islamists, and at other times, to clampdown on oppositional figures and appease segments of the increasingly spreading wave of conservative Islamism which swept the society in the 1970s under Sadat. In doing so, the state has actually utilized a variety of legal instruments to oppress opposition and appease religious conservatism at times when it was deemed needed. One of these legal instruments is the Hisba law, which basically allowed for any citizen to file a case against another on the basis of religious infidelity. It was then left for the judge, after consultation with religious 'state' authorities, to decide the legitimacy of the accusation and the appropriate penalty, if any. The most notorious case which was based on this law and shook local, regional, and international spheres was that of Nasr Hamed Abu-Zaid, the prominent philosopher and university professor who, in 1995, was forced by court order to divorce his wife on the basis of his writings being 'blasphemist' according to the court. ${ }^{6}$

However, in the midst of this myriad of macro and micro sociopolitical alterations and struggles that emerged after 2011, there was a plethora of social and political forces that attempted to push for an agenda of citizenship rights and religious freedoms, both within the 2011-2013 period and also post July 2013. The viable actors and forces within this arena shall constitute the prime focus of this paper.

\section{The Case of Baha'is}

In the wake of the 2011 revolution, Baha'is constituted a relatively small community with an estimated 5000-7000 adherents throughout Egypt. The history of the followers of the Bahai's faith in Egypt dates back to the late 1800s, a period in which Egypt was dominated by the British occupation. At the time, the country was home to a wide array of ethnic and religious minorities and communities, and in the milieu of this diversity, the state provided Baha'is with a sort of recognition that they constitute a distinctive religious group that is separate and distinguishable from Islam. Their presence was generally tolerated by state institutions, and in the 1920s, a governmental religious tribunal reaffirmed their status as a unique religious minority while also highlighting that their teachings are considered as a deviation form Islam. Overall, the Baha'is witnessed a period of relative peace and prosperity during Egypt's famed liberal age (1922-52) (Maghraoui 2006; Effendi 1974). ${ }^{7}$ After the demise of the monarchy and the military takeover of 1952, 
the state's recognition of the Baha'i faith was withdrawn, thanks to the 1960 decree issued by Nasser. As such, their legal status as a recognized religious group was terminated under the Nasser government (Effendi 1974).

The Baha'is ambiguous status under Egyptian law continued to prevail in the postNasser phase. Both the 1971 Constitution and the most recent 2014 Constitution nominally guarantee equal rights and religious freedoms to all Egyptians in one article, while also limiting these liberties to followers of the Abrahamic (Jewish, Christian, and Islamic) religions in another. Practically, they retained a second-degree legal status due to the persistent discrimination they faced with most state institutions. The fact that personal status law in Egypt is guided by religious rather than civil law meant that Baha'is are excluded from this recognition. Consequently, all issues pertaining to their personal and family relations such as inheritance, marriage, and divorce are largely not officiated by the state. $^{8}$

Perhaps the most enduring and probably infamous legal case relating to the situation of Baha'is in Egypt is the one relating to their ID cards. In the late 1990s, the state initiated a policy of computerizing personal records, and accordingly, all citizens were required to be issued new mechanized ID cards. As opposed to the old handwritten ID cards, in which Baha'is were often allowed to leave the religion slot blank or denote their religion as 'Bahai', the new cards had a slot for the religion of each respective citizen which had to be filled automatically with a recognized religion. This left the Baha'is in an existential conundrum owing to the state's refusal to acknowledge their faith as a distinctive religion. (Rieffer-Flanagan 2016). The dilemma was exacerbated further with a specific order issued by the Minister of Interior in 2004 for all relevant authorities to refrain from issuing cards with blank religion slots. ${ }^{9}$ The immediate impact of this official indiscernibility on the lives of Baha'is was profound as they couldn't literally deal with any state authority whatsoever, be it for the purpose of receiving basic services such as health, education, and so on, or even for livelihood matters such as employment, contractual dealings, and tax payments. In short, they were forced into existential oblivion by the state. ${ }^{10}$

In 2006 some activists and rights-based groups filed a lawsuit against the newly enforced policy which yielded the Egyptian Administrative Court ruling that Baha'is have the right to be legally registered by the state. After an elongated legal case that witnessed several revocations and appeals from both sides, in 2009 the Supreme Administrative Court eventually ruled in favor of the Baha'is right to an ID, entailing a return to the prior status quo of a blank slot for religion in the identification card. Despite this positive development, the Baha'i faith remained unrecognized in Egypt, which means that all matters concerning their personal status are not yet officially acknowledged by the state. ${ }^{11}$

\subsection{Post-Revolutionary Realities ... Protraction of Status Quo?}

In the post-2013 era, the situation of Egyptian Baha'is remains dubious, to say the least. Notwithstanding the 2011 revolution, the 1960 decree still stands, which entails that the 2009 verdict is insufficient in terms of granting Baha'is the state's recognition as an official religion. In addition to the state-based discrimination they were exposed to, Baha'is were also subjected to a multitude of social and popular hostilities towards the end of Mubarak's reign. In line with the attacks witnessed by several religious and other minorities and communities in the wake of the increasing rise in the conservative discourse of numerous Salafists, MB, and other Islamist forces in the society after the revolution, the 2011-2013 period also saw instances of unprovoked violence against Baha'i individuals and homes. For example, in February 2011, some Baha'i homes in a locale in the Delta region were immolated by unidentified perpetrators. Several reports alleged that a few state security officers were involved in the attack. "Baha'is are still prohibited from many basic freedoms, such as practicing their religious laws and constructing places of worship. Though Baha'i representatives lobbied during the constitutional drafting processes of 2014 to expand religious freedoms to their community, this did not occur"12. 
In fact, a significant part of the challenges that the Bahai community is exposed to stem from the constitutional vagueness regarding their status. When compared to the constitutions that were drafted after 2011 (in 2012 during the short-lived reign of the MB and then in 2014 at the time of the military-backed government), the 1971 constitution, which was the highest legal document in the country until Mubarak's removal in 2011, is considerably more progressive with regard to religious freedoms and minority rights. For instance, the clauses stating the right of the person to practice religion freely in the 1971 constitution were later omitted in the 2012 and 2014 versions (Baha'i of Egypt' n.d.).

By and large, the 1971 constitution was fairly imbalanced as it saw, on the one hand, very limited clauses on political rights and liberties and the division of powers within the state, and on the other, there were also other articles on personal and civil rights and liberties that were relatively progressive. This can be attributed to Sadat's tendency to portray an image of a country enjoying a decent level of social liberties and freedoms while also maintaining a firm grip over political power. The 1971 constitution also clearly stated that the incorporation of international covenants in the Egyptian legal system is vital. The end result was a relatively incoherent document which left both legislators and judges confused. ${ }^{13}$ Yet several lawyers and human rights activists used the International Covenants on Civil and Political and Economic and Social rights as the basis for their appeals to free some workers accused of demonstrating against state authority and lobbying for strikes, based on the 1971 constitution. A few other cases which witnessed litigations against the state on basis of social and economic rights (the right to have a home, for example) were considerably successful, while others, such as Shiites, were met with massive challenges due to social and political factors. ${ }^{14}$

\subsection{Egyptian Initiative for Personal Rights (EIPR)}

One of the relevant entities that played a key role in promoting the cause of Baha'is and several other ethnic and religious communities and individuals is the Egyptian Initiative for Personal Rights (EIPR), which was founded in 2002 by human rights activist Hossam Bahgat as an Egyptian organization with the aim of protecting and further consolidating human rights. A vast number of the activists, scholars, and practitioners involved in different capacities with EIPR played vital roles in the 2011 revolution, and as such, it's safe to say that the organization was a key platform in the arena of social and political activism, both before and after 2011. In many ways, it emerged to fill the gaps that the traditional rights movement could not occupy. Egypt's human rights movement, which was crystallized in the 1980s and 90s amidst a competition with the Islamist movement over the discourse of social activism during this phase, tended to focus on a certain spectrum of human rights violations that, often, included socioeconomic issues such labor rights, basic needs (or lack thereof) of impoverished classes and communities, and women's rights. It also targeted violations to the personal wellbeing of citizens, which were usually manifested in cases of police brutality and other forms of state violence targeted towards civilians. EIPR, on the other hand, was more willing to engage with the controversial and sensitive issues that were likely to lead to frictions and confrontations with the state. The main activities of the organization consist of research and documentation, litigation, campaigns and lobbying, and fieldwork via its offices, which divide its work into the same three components mentioned above while focusing on their respective regions. The branch offices are operational in Alexandria, the Canal region (Suez, Ismailia, and Port Said), and Luxor, which covers Upper Egypt. ${ }^{15}$

A sizable stifling factor obstructing the work of EIPR in the post-2013 phase was the massive scrutiny, pressure, and most recently, police arrests directed at its key members. In this regard, the organization is not the only civil society entity exposed to such attacks, which come as a part of the methodical and consistent apprehension and targeting that the state security apparatuses practice against several civil society organizations, particularly the ones that work on issues that could potentially be critical of the state, as is the case with EIPR. "In July 2014, when the new civil society law was still being drafted, we 
got to know about it through the leaks published in Al-Ahram. There was no process of community dialogue or transparency on the part of the government whatsoever". ${ }^{16}$ Therefore, the resultant draft was quite problematic as it mainly sanctioned the securitydriven state policies when it comes to the funding of NGO's and other CS actors and reflected the sizable level of control and limitations that the state was intent on applying on all civil society organizations. One of the tools that the law employed to ensure a scope of surveillance over the source of funding of NGOs was a committee called 'Lagnet Al-Fohous' or the Inspection Committee, which was composed of civilian and security state employees and mandated with overseeing the financial inflows coming into any NGO operational in the country. ${ }^{17}$

According to the EIPR members who worked on the Baha'i file, the Baha'i dilemma is a case in point as far as the Egyptian state's conception of citizenship is concerned. The differential treatment that the Egyptian Baha'is have received over the past tend to display that the state's policies and practices towards certain religious minorities is by no means unbiased or equitable.

The religious freedoms portfolio is one of the most important files tackled by EIPR. When someone reports a case, it is assessed based on its placement within the strategic priorities of the organization. The victim/case has to be representative of a bigger issue relating to community-based human rights violations and not just a personal grievance or disagreement on an individual level ... EIPR's work wasn't only focused on Egypt, but also expanded to the MENA region at large. When we received information regarding a certain group or minority being exposed to human rights violations, we would try to approach them. ${ }^{18}$

Due to the relatively limited human and financial resources of an entity such as EIPR, it was pivotal for them to set certain criteria for the selection of the cases they would work on. These included the frequency of recurrence, the geographical/regional scope, and the scale of the violation(s) on hand. Multifaceted aspects of the cases handled had to be managed carefully as well, including, for example, the media exposure or lack thereof that a certain case receives. In the case of the Baha'is, the increasing publicity seemed to correlate with a higher degree of public scrutiny and targeting. In fact, most of the cases of setting Baha'is' homes on fire were reported during the period of media hype revolving around their conundrum, which, in return, forced groups like EIPR to curb their media activities relating to the Baha'i case.

EIPR was engaged with two court cases concerning Baha'is. The first one aimed at granting them the right to denote their religion in the ID cards as Baha'is, and it was lost. The second case is the one mentioned earlier, which ended in the Administrative Court ruling in favor of the Baha'is issuing their own ID cards with a blank slot for religion. Interestingly, despite the fact that the memorandum that the legal team drafted to argue for the cruciality of allowing Baha'is to leave the slot for religion blank was actually based on a pro-rights rationale advocating for religious freedoms, the speech that the team delivered at the court hearing itself wasn't necessarily so.

"We thought the judge was going to be conservative so the final approach we adopted was based on the hypothetical argument that he wouldn't want a Bahai to marry his daughter without knowing his actual belief, hence it is important to differentiate them in the ID. It was framed as a way to protect Muslim houses from Baha'i infiltration and also, from a security standpoint, ensure that the state is able to oversee the actions of a group of the inhabitants who dwell within it. Somehow, it worked."19

Here, it is important to note the role played by law and its dialectical relationship with the society. In the Baha'i case, the law was utilized as an access point rather than a protective or an equitable mechanism that enables individuals to gain their rights. Laws are not created in a vacuum; they are the contextual outcome of the socioeconomic, cultural, and political circumstances prevailing at the time of their creation. Therefore, the pragmatic 
approach adopted by the lawyers in this court hearing is a case in point when it comes to the tactics deployed by human rights defenders in different societies, especially where the legal framework is not necessarily conceived as supportive or favorable for certain groups or minorities.

\section{Bread and Freedom: A Party of the Revolution?}

During the Mubarak period, most opposition political parties were by and large considered as cosmetic instruments willing to be utilized by Mubarak's regime as pawns while offering a façade of pluralism and political participation. They had actually earned the label of 'cartoon' parties, which was widely used in the polity to describe their ineptitude and ineffectiveness in the face of the regime. However, after Mubarak's ousting, most of the limitations which were previously imposed by the regime on the creation and activation of political parties were lifted, and as a result, a lot of the individuals and groups who participated in the 2011 Uprising embarked on the establishment of new parties. The realm of political parties is thus worthy of close scrutiny if one is to navigate through the impact of the 2011 transformations on the discourse and policies relating to citizenship rights and religious freedoms. In doing so, the Bread and Freedom Party (BFP) is one of the prime candidates for such analysis, given the sound correlation between the creation and further development of the party and the events of the 2011 revolution and the fact that they stand out as the one of the few secular political groupings that actively engaged with a host of citizenship-rights-related issues. ${ }^{20}$

In 2012, the project of creating the Bread and Freedom party as an offshoot of the Popular Alliance party, which was an umbrella party established right after the demise of Mubarak's regime in 2011 in order to amalgamate the forces and currents of the political left at the time, was initiated. ${ }^{21}$ Unlike the relatively more seasoned leaders and members of the Popular Alliance who were perceived to be less progressive, or more willing to accommodate some of the policies of the state regarding a variety of social, economic, and political issues, the BFP was mainly composed of a bundle of revolutionary youth who were, according to the leader of the party's politburo, keen on taking a more emphatic stance towards most of these issues, especially with regard to citizenship rights and religious freedoms.

"Citizenship rights should be granted to anyone who inhabits this country ... People should have equal rights and hence it is vital for this struggle to be materialized and fought on everyday basis because it is not merely a legal case or two to be won. We still believe that the current state structure can be reformed from within ... We think that citizenship rights should be earned and that state institutions, such as the judiciary, are actually regressive. Anyone calling for citizenship or equal religious rights is likely to be persecuted, especially if it is against the will of the dominant powers within the state and the society, be it the Islamists from 2011-2013 or the security and military apparatuses afterwards. As such, the state has bestialized and therefore it's only via social and political struggle that we can change that."22

A similar take on the wholistic nature of the struggle for citizenship and the fact that it surpasses a mere set of legal battles was also echoed by the focal point of the citizenship rights portfolio of the BFP. "Litigation is an important component of the battle for more equitable citizenship rights but it's by no means the only one. The democratic movement and the CSOs need to keep on looking for entry points to infiltrate and influence state structures vis-à-vis their approach towards citizenship issues" ${ }^{23}$ Indeed, several elements of the sectarianism and patriarchy in the state have been embedded within its institutions since their foundation, so it's a multifaceted and long-term battle that is likely to last for decades.

One of the main challenges facing the BFP is to attain a sort of a balancing act between the focus on issues of social and economic rights, on the one hand, and civil and political ones, on the other. Being a leftist party with a communist tradition, and given the plethora 
of atrocities and violations witnessed in the socioeconomic arena in a country like Egypt, especially with the labor sector which represents the main constituency of a leftist party like BFP, achieving such a balance is not a straightforward feat, given also its relatively small size and the limited resources it has. "For example, some of our supporters in conservative pockets in Upper Egypt think that we are too liberal because we tend to focus on women and citizenship issues more than workers and farmers. This, of course, isn't quite accurate because we exert our utmost effort to tackle both sets of issues which, more often than not, intertwine at many instances" ${ }^{\prime 2}$. This duality is shown in many of the activities that the BFP has undertaken with the syndicates, farmers unions, and female workers in several factories, where it was clear that the struggle for both sets of rights is closely interlinked. The following section offers a brief overview of the condition of citizenship rights of two of Egypt's most sizable religious groupings, while also highlighting the interventions that were utilized by the BFP in the midst of its efforts to gain a foothold in the struggle for religious freedoms post 2011.

\section{Coptic Christians}

The rise of the Islamists, the oppression of Mubarak's politics, and the general decline in the political forces and groups adopting a leftist agenda meant that a sizable segment of the potential target audience of the leftist camp became increasingly alienated with the leftist current as a whole in the 1980s and 90s. With the increase in terrorist attacks against Coptic Christians during Mubarak's rule in the 1990s and 2000s, and their subsequent targeting in the aftermath of the Islamists' empowerment from 2011-2013, it became clear that the existing representations of the voice and concerns of Coptic Christians in the public sphere was lacking, to say the least (Hamzawy 2014). Throughout Mubarak's reign, the Coptic Church attempted to monopolize the representation of Copts vis-à-vis the state and, more or less, it managed to do so with relative ease.

The massive popularity of Pope Shenouda III, who led the Orthodox Church throughout Mubarak's rule and who was also on good terms with the Mubarak regime thanks to his accommodationist and diplomatic approach towards the state, and the fact that Mubarak's regime also coopted and catapulted the Coptic Church to be considered as the sole representative of all Coptic Christians, again reemphasized the sectarian nature of this relationship. Despite the high hopes that were associated with the 2011 revolution regarding the potential of restructuring this state-church dichotomy, the military-backed government that took over in 2013 ensured that a return to the status quo of this state-church relationship under Mubarak was a reality happening post 2013. Instead of expanding the civic code to be the prime legal framework to which all Egyptians (Muslims and Christians alike) are held accountable, it seemed that post 2013, the state was also keen on maintaining the status quo which was prevalent during Mubarak concerning its relationship with the Coptic Church

In the meantime, various political parties, including BFP, were also quite eager to play an active role in restructuring this dichotomy in a way that allowed for Coptic Christians to be agents of change in the polity and further their own interests with a sense of ownership instead of solely relying on the Church to do so on their behalf.

"The violence and targeting that a lot of Coptic Christians were exposed to in the aftermath of the January 25 revolution led to the resurfacing of a lot of the debates surrounding citizenship rights and religious freedoms in the country. These issues, along with the question of Women's rights (or lack thereof) constitute the pillars of any policy or discourse pertaining to citizenship rights in Egypt today. Hence, the left which has not been very active in these issues because they were supposedly already on the surface of the public debate, had to reengage itself with them again in the post-revolutionary phase. The idea of the Supreme Council of the Armed Forces (SCAF) adopting the extremist Islamists' rhetoric and allegedly mass-murdering Christians in the events of Maspero ${ }^{25}$ in order to silence them was really horrifying on top of it being incomprehensible as well." 26 
In many ways, the BFP attempted to take a more emphatic stance against these episodes of violence that targeted the Christian community in the country. In fact, an integral part of the raison d'etre of BFP (as opposed to other old-school or mainstream 'opposition' parties) is based on this notion of adopting an unequivocal position on issues of sectarianism with little room for compromise. "When [the core group that eventually founded BFP] was still involved with the Popular Alliance, we were keen on being in the field battling against issues of sectarian discrimination. Our members visited Upper Egypt when several locales there were being targeted by extremists in order to show solidarity with the people there and also document the scale of the violations they were exposed to". ${ }^{\prime 27}$

However, there is yet a long way to go regarding any genuine mobilization of viable segments of the Coptic Christian community in the direction of tangible social or political movements calling for more citizenship rights, let alone the direction of leftist parties per se. This can be attributed to a bundle of factors, including the traumatic impact of the 2011-13 period on the majority of the Coptic Christian community and the resultant allegiance that most of it has pledged-via the Coptic Church-to the state institutions, particularly the military and security apparatuses. This adherence to the state, coupled with the historical mistrust towards the left, which was largely in the making since the time of Sadat and more clearly during Mubarak, entailed that the appeal of leftist ideologies and leaders is quite limited within the Coptic Christian community. BFP members recognize this challenge and are aware that a lot more needs to be done in order to showcase that the revolutionary discourse does not actually contradict the interests of the Christian community, but on the contrary, is actually wholly sympathetic and supportive to the demands of the Christian community as far as equitable citizenship rights and religious freedoms are concerned.

\section{The Shiite Question}

Exact figures of the Shiite population in Egypt vary greatly, and there is no official number, given that the state does not include sectarian data in the periodical census. Some estimates state that in the year 2017 their population was around 1,000,000. ${ }^{28}$ (Shi'a of Egypt n.d.) Despite the fact that Egypt is usually considered as a predominantly Sunni society, various aspects of the Shiite doctrine and practices remain deeply imbedded in the Egyptian community. In fact, both the country's capital, which was built around 970 A.D., along with its most prominent religious institution, Al Azhar, came into being at the hands of the Fatimids, who were the first Pan-Islamic Shiite Caliphate rooted in North Africa. The Fatimids ruled Egypt for about 200 years and arguably had the biggest impact on the social habits, belief-systems, and cultural practices of the Egyptians vis-à-vis the other non-native Muslim rulers that reigned over the country. A lot of the cultural facets prevalent contemporarily in Egypt can be traced back to the Fatimids, including the immense reverence of the House (descendants) of Prophet Muhammad, the presence of patron saints who are also venerated in pretty much each major city or town throughout the country, and the abundance of the festivities that are still being celebrated in Egypt today in commemoration of Shiite events such as Ashura and the birthdays of Prophet Muhammad and his family members, such as his grandson, Al Hussein, whose shrine is considered as one of the most visited religious sites in the heart of Cairo.

In spite of these historical and cultural features, the Shiite population remained marginalized for most of Egypt's medieval and modern history. Successive ruling authorities tended to play the Shiite minority as a political card at times of turmoil and instability and the most recent set of episodes relating to the discrimination against Shiites came in the aftermath of the Iranian Revolution in 1979 when Egypt's President Sadat decided to host the ousted Shah of Iran, which juxtaposed the country directly against the newly established Islamic Republic at the time. This, coupled with the fact that the state has become increasingly reliant on Gulf Cooperation Council (GCC) countries for economic and political support ever since the Open-Door policies in 1974, meant that a harsh tone and a firm stance on any manifestations of Shiite rituals or festivities were logical in order 
to appease the ultra-Sunni doctrines dominant within the GCC countries. These policies also aimed at easing some of the fears emanating from the GCC concerning the increasing wave of Shiite spread, which was already on display within other Arab countries with sizable and influential Shiite communities such as Iraq, Lebanon, and most recently, Yemen.

In the post-revolutionary phase, and just like most other minorities, the Shiite voices that were calling for recognition and rights were becoming increasingly audible. Yet the constant rise in the Islamist forces within the state and society from 2011 to 2013 meant that incidents of targeting and persecuting the Shiite community were also on the rise. Most of these forces were predominantly Salafist or pro-Salafist and MB, entailing that they adopted a strictly orthodox interpretation of Sunni Islam and perceived non-Orthodox Muslims such as the different Shiite sects and Alawites, among others, as deviators from the core of Islam. This wave of state-society intolerance of the Shiites also affected institutions such as Al Azhar, which, despite its historical affiliation with the Shiite doctrine and the fact it acknowledges the Shiite school of thought in some of its curricula, also joined in this wave of antagonism against Shiites by declaring in 2013 that the Shiite practices actually stand against the tenets of proper Islam.

"The Grand Imam of Al-Azhar, Ahmed Al-Tayyeb, has used television appearances to implore his audience to beware of Shi'a proselytizers. Moreover, the Ministry of Religious Endowments runs mosques in Egypt in accordance with Sunni doctrine and does not recognize Shi'a mosques or rituals. In May 2015 a Shi'a dentist from Daqahlia governorate received a six-month prison sentence for contempt of religion after authorities found in his home books and other items supposedly used to perform Shi'a religious rituals. A week later, Shi'a cleric Taher al-Hashimy was arrested following a raid on his apartment where books and other items were confiscated by security forces." 29

As an institution, Al-Azhar was attempting to assert its own power as the 'official' representative of Sunni Islam in Egypt vis-à-vis Salafists, MB, and other conservative forces, while also consolidating its credentials as the protector and keeper of Sunni Islam, especially in the battle of legitimacy of Egyptian state institutions post 2011 and the geopolitical context in the region in light of the rivalry between KSA and Iran.

This overwhelming state of hostility against Shiites eventually led to a spike in the incidents of aggression and violence against their communities and households. One of the most publicized attacks took place in June 2013, a few days before the mass protests on June 30, 2013, when a mob led by ultra-Salafists launched an attack on a group of Shiites celebrating a religious ceremony at a private house in a village in Giza. "Though four men were killed, including a prominent Shi'a figure, Sheikh Hassan Shehata, and other Shi'a houses were also set on fire, the police allegedly failed to take action to halt the attacks". ${ }^{30}$ The incident actually came after a period of antagonistic sermons by local Salafi preachers in the communal mosques of the village where the attack happened.

The BFP was probably one of the few parties that managed to engage with the debate relating to the Shiite community in Egypt. Despite the religious sensitivity of the matter and the fact that there were sizable social and political prices to be paid by the party as a result, its core members were still adamant on tackling that file due to its priority as a clear breach of the citizenship rights of Shiite Egyptians. The party managed to attract some Shiite youth into its ranks, most of whom had converted to (or embraced) Shiism due to what they perceived to be the appalling nature of the rhetoric and policies of the ultra-conservative groups such as the Salafists and the MB. The fact that the ideas and allegiances of Shiites in a country like Egypt pose a sense of minority resistance to the overwhelming majority makes them also somehow appealing to a lot of the leftists who usually tend to support the struggle of smaller social and political groups against the hegemonic state. For the most part, and because of the considerably high stakes involved, embracing Shiism in Egyptian society has become a political and a social commitment in addition to being a religious and a theological one. 


\section{Alexandria}

Historically, Alexandria was one of the most multicultural and open communities in modern Egypt. As the country's main port, and with a long and ancient tradition of coexistence with and close proximity to southern Mediterranean communities of Greeks, Italians, and Turks, among others, the city was, in many ways, a cornerstone of regional and international economic and cross-cultural exchange up until the mid-20th Century. This picture changed gradually after 1952, and by the 1970s, a significant part of this internationalisation was non-existent due to a multitude of socioeconomic and political factors.

Contemporarily, Alexandria is characterized by a bundle of socioeconomic, cultural, and topographical features that distinguish it from Cairo, and subsequently affected the dynamics relating to Egypt's second largest city's experiences with the January 25 Uprising and the mobilizational events that ensued afterwards. As opposed to Cairo's Tahrir Square, which served as a mega-hub and a gathering point for the various social and political groupings participating in the mobilization, the Alexandrian protesters, on the other hand, had to come up with alternatives, as there was no such parallel structure in their city. "We used to roam around the streets and cross paths with people from different walks of life, age-groups and, of course, political affiliations. This allowed for a constant space for dialogue and, often, conflict with different segments of the Alexandrian society ... The experience here was thus relatively different. It gave us the opportunity to be exposed to and the expertise to engage with different viewpoints unlike Tahrir where the majority was those who wanted to be there" ${ }^{31}$ The rather intimate setting of Alexandria's mobilizations also entailed that most of the social and political groups who were interested in a particular cause related to the revolution would eventually get to know each other through common activities and experiences. This facilitated coordination between the various forces irrespective of their ideological platforms, as manifested in the Alexandrian secular and democratic forces' ability to create various unified fronts that combined social and political forces from different platforms and managed to jointly organize common activities and participate in some electoral events as a collective.

A facet that also distinguishes Alexandria from Cairo is the fact that it is relatively smaller in terms of geographical area. Neighborhoods and communities are within close proximity to each other and can be differentiated from one another on the basis of socioeconomic class, educational levels, predominant cultural and political affiliations, and so on. This makes the targeting process of certain groups and communities much more focused, as it enables the political actors to clearly zero-in on their target audiences, and accordingly, devise their communication messaging tactics and strategy in line with the typology of the prospective stakeholders. This has also led to the city being comparatively condensed with specific constituencies that are often at odds with each other. "In Alexandria, entry points are clearer vis-à-vis Cairo ... We are more concentrated here. You will find high percentages of religious extremism as well as strong support for the secular ideology and parties. This was shown in the electoral events that preceded 2013 in which the Salafist current was allowed to run freely and amassed a sizable chunk of the votes" ${ }^{\prime \prime 2}$. In the meantime, the Alexandria Governorate also harbored one of the most active anti-Islamist oppositions before 2013, which was reflected in the considerable percentage of opposition votes that the draft constitution of 2012 received when it was put to vote. ${ }^{33}$ When compared to other regions throughout the country, Alexandria actually saw one of the highest turnouts against this constitutional referendum of 2012.

Just like in Cairo and the other governorates, the capacity of some of the activists involved in the left to multifunction on several fronts of sociopolitical and economic struggle against the predominant authorities is yet limited:

"Some people do not conceive the importance of working simultaneously on different angles and themes. Workers, for instance, only conceive citizenship through equal economic rights, not equal access to opportunities regardless of religion, sect or gender. Those who are burdened by citizenship concepts other 
than inequality of economic benefits are usually upper and middle bourgeoisie. For instance, although a female Christian worker could be experiencing multiple tiers of discrimination, she would still focus on the economic aspects due to her conviction that if she would engage with issues that relate to religious freedoms, for example, then she would be backing out on her major battle." 34

Due to the entrenched centrality of Cairo in most of the social and political structures in the country, including political parties and other groupings, the 'brains' have been predominantly coming from Cairo. This means that the agendas, platforms, and sometimes even priorities of action of most of the mobilization taking place used to be directed based on Cairo. Several revolutionary parties attempted to adopt a different model based on decentralization, but it is an experience that is yet to be assessed. Due to such factors of close proximity and relatively small area, it was also more difficult for the human rights and democratic movements to tackle certain issues, especially the ones that received general social attention and caused controversial debates and heat within society, such as homosexuality or the rights of the Baha'i community, as opposed to other causes perceived to be less controversial, like the discrimination against Coptic Christians in some workplaces, for instance.

\section{Conclusions}

The concept of citizenship has been used by a multitude of social and political forces in the aftermath of the Egyptian uprising, sometimes in conflicting ways. On the one hand, the state has - at various junctures - attempted to monopolize the process of interpreting and operationalizing the concept, mostly on its own terms, in order to highlight notions that relate to 'nationalism' rather than citizenship, such as the responsibilities of the 'citizens' and their perceived loyalty to their homeland. On the other hand, a plethora of the social and political forces and movements that actively participated in the Egyptian uprising seemed to be pushing for an agenda of 'citizenship rights' that advocates equality between the subjects of the state regardless of religion, ethnicity, creed, color, and so on, and calls on the state to uphold its role as a guarantor of equal rights to all citizens. As shown in this paper, there is also a growing body of CSOs that have been engaged in an array of projects revolving around the theme of citizenship rights, a lot of which have gained bigger momenta post January 25.

This state-society dichotomy has shaped the features of the discourse on citizenship and the rights associated with it throughout Egypt's modern history. Since Mubarak's ousting, there have been several shifts in the dominant power relations within the polity, which influenced the evolution of citizenship rights in Egypt. Subsequently, the rights discourses of political actors, be it state institutions such as the military and the relevant ministries or the informal political movements and formal political parties, were inconsistent at times. At certain points during the transition, the exercise of some citizenship rights has been actualized, but they have also been subjected to attacks and restrictions at other times. More often than not, citizenship rights that require revisiting certain religious and cultural norms to support their application, such as religious freedoms, have been limited due to the tendency of the dominant political forces to use populist rhetoric and attract larger numbers of supporters among more powerful societal groups.

The ethnographic approach adopted in this writing offers a deeper look into the trials and tribulations of some of the social and political movements associated with various issues of citizenship rights, against the backdrop of the January 25 Revolution. In pursuing a civil/political agenda, the experiences of many of these social and political actors represent an example of practicing active citizenship via working on the rights associated with it. However, as highlighted by some of them, these experiences are not without limitations. The groups involved in such activities remain to be from a certain socioeconomic class that is predominantly within the upper middle and well-educated segments of the society. For the most part, they can't be considered as part of a grassroots movement claiming their rights. Henceforth, a sizable portion of the debates and deliberations on issues of 
citizenship rights remain to be limited within elite circles of activists, academics and some of the intelligentsia involved or concerned with these issues.

A plethora of the social and political activists engaged with citizenship rights have embarked on multiple struggles aiming at raising more awareness among the popular echelons of the society regarding some of these rights, while also working on creating, amending, or abolishing laws related to the social status of several groups of religious minorities. Some of them do believe that even if the strategic objective is to overthrow the entire legal system, or radically change it, the micro-level struggle is still also pivotal. This means that the short-term tactical approaches—as well as the strategic ones-are both vital for this kind of confrontation between the sociopolitical forces, on the one hand, and the relevant state authorities, on the other. Thus, the importance of the litigations advocated by democratic and human rights movements, and their ramifications regarding furthering the cause of religious freedoms, for example, cannot be understated. The findings of the fieldwork conducted for the purpose of this study contribute to our understanding of citizenship and religion by showcasing the challenges that face some of these social and political activists and practitioners as they attempt to actualize their role on the ground. In doing so, the study highlights that the battle for citizenship rights in Egypt is likely to be a long-term and multifaceted one, involving structural changes within the power dynamics of state-society relations.

The increasing suppression that a few of the human rights and political movements discussed in this paper, such as EIPR and BFP, were exposed to post 30 June 2013 shows that the state is intent on limiting the potential of sociopolitical pressure emanating from the society with regard to citizenship rights and religious freedoms. This is coupled with a clear tendency to pursue the policies of the pre-2011 era concerning the confiscation and monopolization of the discourse and policies relating to the role of religion in the society. In doing so, the state reinvigorates the top-down approach adopted since 1952 concerning the actualization of the relevant spectrum of citizenship rights.

Funding: This research was partially funded by ACSS.

Institutional Review Board Statement: The study was conducted according to the guidelines of the Declaration of Helsinki, and approved by the Arab Council of Social Sciences.

Informed Consent Statement: Informed consent was obtained from all subjects involved in the study.

Conflicts of Interest: The authors declare no conflict of interest.

\section{Interviews:}

Refaat Abdelkarim, CARE International, Cairo, February 2017

Amr Abdelrahman, EIPR and and Center for Law \& Society, Cairo, April 2016

Jano Charbel, Human Rights Activist, Cairo, June 2011

Elham Eidarous, BFP, Cairo, January 2017

Mona Ezzat, BFP and New Woman Foundation, Cairo, October 2016

Bahaa Ezz El-Arab, EIPR, Cairo, January 2016

Akram Ismail, BFP, Cairo, June 2016

Nabil Morqos, Independent Development Consultant, Cairo, 2016

Susan Nada, BFP, Alexandria, September 2016

Khaled Tawhid, Permanent Workers Conference, Alexandria, September 2016

\section{Notes}

This principle is evidently present in all of the country's constitutions from 1923 onwards, however, the application of certain laws, such as the one for building place of worship, sometimes reflected discrepancy and, at times, discrimination againts Coptic Christians.

2 The term 'dhimmi' refers to the Islamic Jurisprudent description of non-Muslims living within the boundaries of Islamic societies. The legal status of the majority of non-Muslims communities living under the various Islamic caliphates was defined by this term, which implied that they were granted state protection in return for paying 'Jizya' or special tax. With the advent of the predominantly secular nation-state projects in most of the Muslim societies in the early 20th Century, the term 'dhimmi' became 
rather controversial as it was perceived by the seculars and liberals as a discriminatory concept that doesn't grant equal rights to all citizens. As such, its usage began to be limited and mostly associated with the Islamic schools of thought.

3 Figures like Nabil Morqos, Akram Ismail, Bahaa Ezzelarab, Mona Ezzat and Amr Abdelrahman were all engaged in a wide variety of schemes concerning citizenship rights at various junctures before and after the 2011 Revolution. Morqos is an Egyptian intellectual and a development expert, who's been engaged in the field of civil society for over five decades, Ezz-El Arab is a legal expert and was in charge of the litigation arm of the Egyptian Initiative of Personal Rights (EIPR) at the time of writing this paper. He also participated actively in the January 25 Uprising. Eidarous is the focal point of the civil and political rights portfolio in the Bread and Freedom Party.

4 For example, whereas Nabil Morqos' focus was mostly on the socioeconomic rights of the citizens and the essentiality of highlighting this theme in any study/scrutiny of citizenship rights in a country like Egypt, other activists and practitioners, such as Bahaa Ezz-El Arab and Elham Eidarous, emphasized the cases of civil and political rights abuses as the most striking forms of infringement on citizenship rights.

$5 \quad$ Articles \#1 and 6 of the Egyptian Constitution of 2014.

6 The law was based on the 1971 constitution's assertion that Shariaa is a source of legislation. It was then modified to allow only for the public prosecutor to decide validity of claims instead of granting individuals the right to raise cases in court directly. Another case in point here is Law \# 98 (concerning religious blasphemy); a largely ambiguous law that's mostly used against non-Muslims for 'insulting' Islam, which is an extremely vague notion as it's not clearly stipulated in the law itself and mainly left for the interpretation of Judges. The number of writers and intellectuals who were put on trial as a result of this law expounded after 2011 and continued to increase even after 2013.

7 See: Shoghi Effendi (1974). Baha'i Administration, Selected Messages 1922-1932. Wilmette, IL: Bahá'í Publishing Trust.

8 See: 'Baha'i of Egypt'. World Directory of Minorities and Indigenous Peoples. Minority Rights Group International. https:// minorityrights.org/minorities/bahai-of-egypt/\#: :text=The\%20group $\% 20$ has $\% 20 \mathrm{a} \% 20$ well, annulled $\% 20$ under $\% 20$ the $\% 20 \mathrm{Nasser} \%$ 20government. (accessed on 15 January 2021).

Ibid.

Ibid.

Interview with Bahaa Ezz El-Arab, Cairo, January 2016.

Baha'i of Egypt'. World Directory of Minorities and Indigenous Peoples. Minority Rights Group International. https:// minorityrights.org/minorities/bahai-of-egypt/\#: :text=The\%20group $\% 20$ has $\% 20$ a $\% 20$ well, annulled $\% 20$ under $\% 20$ the $\% 20 \mathrm{Nasser} \%$ 20government. (accessed on 15 January 2021).

Sadat's bid to portray himself and his regime as the protectors of Islamic piety and values was also reflected in the novel inclusion of the term 'Shariaa' into the preamble of the 1971 constitution. Article \# 2 which previously read: "Islam is state's religion and Arabic is its official language" was modified to "Islam is the state's religion; Arabic is its official language and the principles of Islamic Shariaa are a main source of legislation". Interview with Amr Abdelrahman, Head of Civil \& Political Rights Program, EIPR, Cairo, April 2016.

Ibid.

Ibid.

After episodes of local and international opposition to the new draft law it was eventually scrapped and reintroduced in a modified and reformed format in 2019. The new draft affords more flexibility for CSO's in terms of funding, and in doing so, it also removed the security apparatuses personnel representation from the Committee. Interview with Bahaa Ezz El-Arab, Cairo, January 2016.

Ibid.

In the aftermath of the Jan 25 revolution, several other secular political parties were also created with the aim of fostering the socioeconomic and political objectives of the January 25 movement, representing a variety of ideological platforms. These include parties such as the centrist Egyptian Social Democratic Party (ESDP), the Baradei-led Dostour (Constitution) Party and the social-liberal Egypt's Freedom Party.

21 Up until the time of this writing, and in spite of its structural presence and ongoing activities, the BFP wasn't yet recognized as an official party by the state due to its inability to collect a required threshold of 5000 signatures from 10 different Egyptian governorates. This caused the party to be exposed to numerous cases of harassment by state security apparatuses, especially in the aftermath of the June 2013 movement, whereby some of its members where subject to pretrial detention. Interview with Akram Ismail, BFP Politburo, Cairo, June 2016.

Interview with Elham Eidarous, focal point of the citizenship rights portfolio, BFP, Cairo, Jan 2017.

Interview with Akram Ismail, BFP Politburo, Cairo, June 2016.

In 2012, more than 20 Coptic Christian demonstrators were killed in confrontations with military troops in the neighborhood of Maspero on the Nile Corniche. The Military later denied any responsibility for the deaths of demonstrators and blamed it on 'third party' elements who had an interest in agitating sectarian conflict by antagonizing the situation between Coptic Christians and the SCAF. 
Interview with Akram Ismail, BFP Politburo, Cairo, June 2016.

Ibid.

'Shi'a of Egypt'. World Directory of Minorities and Indigenous Peoples. Minority Rights Group International. https:/ / minorityrights. org/minorities/shia-of-egypt/ (accessed on 15 January 2021).

Ibid.

Ibid.

Interview with Susan Nada, BFP Alexandria Office Coordinator, Alexandria, September 2016.

Ibid.

Ibid.

Interview with Susan Nada, BFP Alexandria Office Coordinator, Alexandria, September 2016.

\section{References}

Abou-Habib, Lina. 2011. The 'right to have rights': Active citizenship and gendered social entitlements in Egypt, Lebanon and Palestine. Gender \& Development 19: 441-54.

Al Bishri, Tarek. 2004. Al-Muslimūn wa-al-Aquāt fì ițār al-jamā'ah al-Wațanīyah. Cairo: Dar Al Shorouk.

Assad, Ragab, and Motaz Al Fegeiri. 2014. Citizenship in Post-Awakening Egypt: Power Shifts and Conflicting Perceptions: Challenges for EU and US Foreign Policy; EUSpring, January. Available online: https:/ / cihrs.org/citizenship-in-post-awakening-egypt-powershifts-and-conflicting-perceptions/?lang=en (accessed on 10 February 2021).

Ayubi, Nazih. 1995. Overstating the Arab State. London: I. B. Tauris.

Baha'i of Egypt'. n.d. World Directory of Minorities and Indigenous Peoples. Minority Rights Group International. Available online: https:/ / minorityrights.org/minorities/bahai-of-egypt/\#: \{\}:text=The\%20group\%20has\%20a\%20well,annulled\%20under\% 20the\%20Nasser\%20government (accessed on 15 January 2021).

Bayat, Asef. 2007. Making Islam Democratic: Social Movements and the Post-Islamist Turn. Stanford: Stanford University Press.

Bayat, Asef. 2013. Life as Politics: How Ordinary People Change the Middle East. Stanford: Stanford University Press.

Brown, Nathan. 2013. Egypt's Failed Transition. Journal of Democracy 24: 4. [CrossRef]

Butenschon, Nils, Uri Davis, and Manuel Hassassian. 2000. Citizenship and the State in the Middle East: Approaches and Applications. Syracuse: Syracuse University Press.

Effendi, Shoghi. 1974. Baha'i Administration, Selected Messages 1922-1932. Wilmette: Bahá'í Publishing Trust.

El-Mahdi, Rabab. 2011. Empowered Participation or Political Manipulation? State, Civil Society and Social Funds in Egypt and Bolivia. Leiden and Boston: Brill.

Farah, Tawfic E. 2019. Pan-Arabism and Arab Nationalism: The Continuing Debate. Milton Park: Routledge.

Ghanem, Hafez. 2014. Improving Regional And Rural Development For Inclusive Growth In Egypt. Washington, DC: The Brookings Institution.

Hamzawy, Amr. 2014. On religion, politics and democratic legitimacy in Egypt, January 2011-June 2013. Philosophy E Social Criticism 40: 401-6.

Jandora, John W. 2008. States without Citizens. Understanding the Islamic Crisis. New York: Praeger.

Jones, Emma, and Gaventa John. 2002. Concepts of Citizenship: A Review. Sussex and Brighton: Institute of Development Studies.

Joseph, Suad. 2000. Gender and Citizenship in the Middle East. Syracuse: Syracuse University Press.

Karkabi, Nadeem. 2013. Lifestyle Migration in South Sinai, Egypt: Nationalisation, Privileged Citizenship and Indigenous Rights; International Review of Social Research. Available online: https://irsrjournal.unibuc.ro/wp-content/uploads/2020/11/Lifestyle-Migrationin-South-Sinai-Egypt_-Nationalisation-Privileged-Citizenship-and-Indigenous-Rights.pdf (accessed on 10 February 2021).

Maghraoui, Abdesalam. 2006. Liberalism without Democracy: Nationhood and Citizenship in Egypt 1922-1936. Durham: Duke University Press.

Marshall, Thomas. Humphrey. 1973. Class, Citizenship and Social Development. Westport: Greenwood, First publihsed 1959.

Meijer, Roel, and Nils Butenschon. 2017. The Crisis of Citizenship in the Arab World. Leiden: Brill.

Menza, Mohamed F. 2012a. Neoliberal Reform and Socio-Structural Reconfiguration in Cairo's Popular Quarters: The Rise of the Lesser Notables in Misr Al Qadima. Mediterranean Politics 17: 322-39. [CrossRef]

Menza, Mohamed F. 2012b. Patronage Politics in Egypt: The National Democratic Party and Muslim Brotherhood in Cairo. Milton Park: Routledge.

Moghadam, Valentine M. 2003. Engendering citizenship, feminizing civil society: The case of the Middle East and North Africa. Women E Politics 25: 63-87.

Pizzo, Paola. 2015. The 'Coptic question' in post-revolutionary Egypt: Citizenship, Democracy, Religion. Ethnic and Racial Studies 38: 14. [CrossRef]

Qelada, William. 1999. The Principle of Citizenship: Studies and Articles. Cairo: Maktabat al-Usrah. (In Arabic)

Rieffer-Flanagan, Barbara Ann. 2016. Statism, Tolerance and Religious Freedom in Egypt. Muslim World Journal of Human Rights 13: 1. [CrossRef]

Sater, James. 2013. Citizenship and Migration in in Arab Gulf Monarchies. In Migration, Security and Citizenship in the Middle East. Edited by Peter Seeberg and Zaid Eyadat. Basingstoke: Palgrave Macmillan. 
Shami, Seteney. 2009. Aqalliya/Minority in Modern Egyptian Discourse. In Words in Motion: Towards a Global Lexicon. Edited by Carol Gluck and Anna Tsing. Durham: Duke University Press.

Shi'a of Egypt. n.d. World Directory of Minorities and Indigenous Peoples. Minority Rights Group International. Available online: https://minorityrights.org/minorities/shia-of-egypt/ (accessed on 15 January 2021).

Soliman, Samer. 2011. The Autumn of Dictatorship: Fiscal Crisis and Political Change in Egypt under Mubarak. Palo Alto: Stanford University Press.

Stadnicki, Roman, Vignal Leila, and Barthel Pierre-Arnaud, eds. 2014. Arab Cities after the 'Spring'. Built Environment. Marcham: Alexandrine Press, vol. 40.

Takawi, Mourad. 2012. Modernizing the Coptic Community [Manuscript]: The Laity-Clergy Struggle for Communal Representation and the Road to the 1911 Asyūt Congres. Master's Thesis, American University in Cairo, New Cairo, Egypt.

Butenschon, Nils, Uri Davis, and Manuel Hassassian. 2000. Islam, Civil Society and Citizenship. Reflections on the Sociology of Citizenship in Islamic Societies. In Citizenship and the State in the Middle East. Approaches and Applications. Butenschon, Nils, Uri Davis, and Manuel Hassassian. Syracuse: Syracuse University Press, pp. 28-48.

Young, Iris. 1989. Polity and Group Difference: A Critique of the Ideal of Universal Citizenship. Ethics 99: 2. [CrossRef] 